\title{
Quinone-induced Enhancement of DNA Cleavage by Human Topoisomerase Ila: Adduction of Cysteine Residues 392 and
}

\section{$405+$}

\author{
Ryan P. Bender $\ddagger$, Amy-Joan L. Ham $\ddagger$,, and Neil Osheroff $\ddagger, \perp,{ }^{*}$ \\ Departments of Biochemistry and Medicine (Hematology/Oncology), and Mass Spectrometry \\ Research Center, Vanderbilt University School of Medicine, Nashville, Tennessee 37232-0146
}

\section{Abstract}

Several quinone-based metabolites of drugs and environmental toxins are potent topoisomerase II poisons. These compounds act by adducting the protein, and appear to increase levels of enzymeDNA cleavage complexes by at least two potentially independent mechanisms. Treatment of topoisomerase II $\alpha$ with quinones inhibits DNA religation, and blocks the N-terminal gate of the protein by crosslinking its two protomer subunits. It is not known whether these two effects result from quinone adduction to the same amino acid residue(s) in topoisomerase II $\alpha$ or whether they are mediated by modification of separate residues. Therefore, the present study identified amino acid residues in human topoisomerase II $\alpha$ that are modified by quinones and determined their role in the actions of these compounds as topoisomerase II poisons. Four cysteine residues were identified by mass spectrometry as sites of quinone adduction: cys170, cys392, cys405, and cys455. Mutations (cys->ala) were individually generated at each position. Only mutations at cys392 or cys 405 reduced sensitivity ( $\sim 50 \%$ resistance) to benzoquinone. Top $2 \alpha \mathrm{C} 392 \mathrm{~A}$ and top $2 \alpha \mathrm{C} 405 \mathrm{~A}$ displayed faster rates ( 2-fold) of DNA religation than wild-type topoisomerase II $\alpha$ in the presence of the quinone. In contrast, as determined by DNA binding, protein clamp closing, and protomer crosslinking experiments, mutations at cys392 and cys 405 did not affect the ability of benzoquinone to block the $\mathrm{N}$-terminal gate of topoisomerase II $\alpha$. These findings indicate that adduction of cys 392 and cys 405 is important for the actions of quinones against the enzyme, and increases levels of cleavage complexes primarily by inhibiting DNA religation.

Topoisomerase II $\alpha$ is an essential enzyme that plays important roles in a number of growth related processes in human cells, including DNA replication and chromosome segregation. The enzyme removes superhelical twists, knots, and tangles from the genetic material by generating transient double-stranded breaks in the backbone of DNA (1-7). To maintain genomic integrity during this cleavage event, the enzyme forms covalent bonds between active site tyrosyl residues and the 5'-DNA termini created by scission of the double helix (8-10). Although these transient covalent topoisomerase II $\alpha$-cleaved DNA complexes (i.e., cleavage complexes) are requisite intermediates in the catalytic cycle of the enzyme, their presence is

\footnotetext{
$\dagger$ This work was supported by National Institutes of Health research grants GM33944 (NO). RPB was a trainee under grant 5 T32 CA09582 from the National Institutes of Health.

* To whom correspondence should be addressed. Tel: 615-322-4338. Fax: 615-343-1166. neil.osheroff@vanderbilt.edu.. \#Department of Biochemistry.

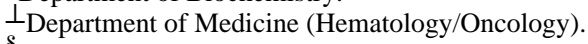

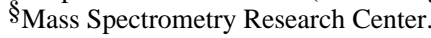

SUPPORTING INFORMATION AVAILABLE

Representative spectra of plumbagin adducted peptides of human topoisomerase II $\alpha$. This material is available free of charge via the Internet at http://pubs.acs.org.
} 
potentially deleterious to the cell. When a DNA tracking system, such as a replication fork, attempts to traverse a cleavage complex, the transient enzyme-bound DNA break often is converted to a permanent strand break $(1-4,7)$. Thus, conditions that significantly increase the concentration of topoisomerase II $\alpha$-DNA cleavage complexes trigger illegitimate recombination, chromosomal aberrations, and cell death pathways (4,11-16).

Agents that increase levels of topoisomerase II $\alpha$-mediated DNA strand breaks are termed topoisomerase II poisons to distinguish their mechanism of action from compounds that act by inhibiting the overall catalytic activity of the enzyme (i.e., catalytic inhibitors) $(4,15$, 17-19). Topoisomerase II poisons play important roles in both the treatment and the development of human cancers. Approximately one-half of all cancer chemotherapy regimens contain drugs that target the type II enzyme. Furthermore, several topoisomerase II poisons that are naturally found in fruits and vegetables, such as bioflavonoids, are believed to have chemopreventative properties (20-23). Conversely, a small number of patients who receive therapy that includes topoisomerase II-targeted drugs develop secondary leukemias. These drug-related leukemias commonly feature aberrations (deletions, duplications, and translocations) in the mixed-lineage leukemia $(M L L)$ gene at chromosomal band 11q23 (13, 14,24-29). In addition, the same bioflavonoids that are beneficial for adult health, when ingested during pregnancy, are believed to increase the risk of infant leukemias that include $M L L$ rearrangements (30-34).

Recently, a number of toxic quinone-based metabolites of drugs or environmental pollutants have been found to be potent human topoisomerase II poisons (35). These include $N$-acetyl$p$-benzoquinone imine (derived from acetaminophen) (36), benzoquinone (derived from benzene) $(37,38)$, as well as several polychlorinated biphenyl (PCB) ${ }^{1}$ metabolites (39). Exposure to these compounds causes DNA strand breaks and other chromosomal aberrations, and has been linked to a variety of human health problems, including cancer (40-44). To this point, the accumulation of benzoquinone in the bone marrow is believed to contribute to the leukemogenic properties of benzene (41). Moreover, genetic deficiencies in NAD(P) H:quinone oxidoreductase 1, the enzyme that reduces benzoquinone to the less reactive hydroquinone, are linked to the formation of leukemias with $M L L$ rearrangements (45-49).

The quinone-based topoisomerase II poisons differ from "classic" topoisomerase II poisons (such as etoposide and bioflavonoids) in two ways. First, quinones are mixed-function inhibitors of the type II enzyme: they increase DNA scission when added to a topoisomerase II-DNA complex, but inhibit scission when incubated with the enzyme prior to the addition of nucleic acids (36-39,50-54). Second, in contrast to compounds like etoposide (which interact with topoisomerase II in a non-covalent manner), quinones act by covalently attaching to the protein $(35-39,53)$.

Because of the human health concerns of quinone-based topoisomerase II poisons and their unusual mode of action against the type II enzyme, sites of quinone adduction on human topoisomerase II $\alpha$ were mapped by mass spectrometry. Four cysteine residues were identified and mutated to alanine residues. Two of the mutant enzymes, top $2 \alpha \mathrm{C} 392 \mathrm{~A}$ and top $2 \alpha \mathrm{C} 405 \mathrm{~A}$, displayed decreased sensitivity to benzoquinone and the PCB quinone 4' $\mathrm{Cl}-2,5 \mathrm{pQ}$. These findings strongly suggest that adduction of cysteine residues 392 and 405 play a role in the actions of quinones against human topoisomerase II $\alpha$.

${ }^{1}$ Abbreviations: PCB, Polychlorinated biphenyl; 4’Cl-2,5pQ, 2-(4-chloro-phenyl)-[1,4]benzoquinone. 


\section{EXPERIMENTAL PROCEDURES}

\section{Enzymes and Materials}

Human topoisomerase II $\alpha$ was expressed in Saccharomyces cerevisiae and purified as described previously (55-57). Mass spectrometry grade trypsin and chymotrypsin were obtained from Fisher and Princeton Separations, respectively. Negatively supercoiled pBR322 DNA was prepared using a Plasmid Mega Kit (Qiagen) as described by the manufacturer. Benzoquinone, plumbagin, and etoposide were obtained from Sigma, prepared as $20 \mathrm{mM}$ stock solutions in $100 \%$ DMSO, and stored at $4{ }^{\circ} \mathrm{C} .4^{\prime} \mathrm{Cl}-2,5 \mathrm{pQ}$ (the generous gift of Dr. Hans J. Lehmler, University of Iowa) was synthesized by coupling 4'-chloroaniline with 1,4benzoquinone (58). The compound was prepared as a $20 \mathrm{mM}$ stock in $100 \% \mathrm{DMSO}$, and stored at $-20^{\circ} \mathrm{C}$. All other chemicals were of analytical reagent grade.

\section{Adduction of Topoisomerase lla by Quinones}

To determine sites of quinone adduction on human topoisomerase II $\alpha, 135 \mathrm{~nm}$ enzyme was incubated in a total of $300 \mu \mathrm{L}$ of cleavage buffer $(10 \mathrm{mM}$ Tris- $\mathrm{HCl}, \mathrm{pH} 7.9,100 \mathrm{mM} \mathrm{KCl}, 5$ $\mathrm{mM} \mathrm{MgCl} 2,0.1 \mathrm{mM} \mathrm{NaEDTA}$, and $2.5 \%$ glycerol) in the presence of $250 \mu \mathrm{M}$ plumbagin for $10 \mathrm{~min}$ at $37^{\circ} \mathrm{C}$. Reactions were quenched with $20 \mu \mathrm{L}$ of $45 \mathrm{mM}$ DTT. Samples were applied to 30,000 NMWL filter columns (Millipore), washed with $10 \%$ methanol in $25 \mathrm{mM}$ ammonium bicarbonate, and resuspended in $25 \mu \mathrm{L}$ of $25 \mathrm{mM}$ ammonium bicarbonate. DTT ( $2.5 \mu \mathrm{L}$ of 45 $\mathrm{mM})$ was added, and the protein was incubated for $15 \mathrm{~min}$ at $50{ }^{\circ} \mathrm{C}$. Iodoacetamide $(2.5 \mu \mathrm{L}$ of $100 \mathrm{mM}$ ) was added and the sample was incubated at room temperature in the absence of light for $15 \mathrm{~min}$. Additional DTT ( $2.5 \mu \mathrm{L}$ of $45 \mathrm{mM})$ was added to quench the iodoacetamide, and the protein was incubated for $15 \mathrm{~min}$ at $50{ }^{\circ} \mathrm{C}$. Samples were washed with $10 \%$ methanol in $25 \mathrm{mM}$ ammonium bicarbonate and resuspended in $25 \mu \mathrm{L}$ of $25 \mathrm{mM}$ ammonium bicarbonate. Trypsin $(0.1 \mu \mathrm{g})$ was added and samples were incubated for $16 \mathrm{~h}$ at $37^{\circ} \mathrm{C}$ to digest the protein. Alternatively, chymotrypsin $(0.1 \mu \mathrm{g})$ was added and samples were incubated for $6 \mathrm{~h}$ at room temperature. Peptides were eluted from the column, dried and reconstituted in $0.1 \%$ formic acid for mass spectral analysis.

Residues in topoisomerase II $\alpha$ that were adducted by quinone were identified by mass spectral analysis of the tryptic or chymotryptic peptides. The LC-MS/MS analyses were performed on a ThermoFinnigan LTQ linear ion trap mass spectrometer equipped with a ThermoFinnigan

Surveyor LC pump and autosampler, NanoSpray source (Thermo Electron), and Xcalibur 1.4 instrument control and data analysis software. HPLC separation of the tryptic peptides was achieved using a $100 \mu \mathrm{m} \times 11 \mathrm{~cm} \mathrm{C}-18$ capillary column (Monitor C18, 5 micron, 100 angstrom, Column Engineering) at a flow rate of $0.7 \mu \mathrm{L} \mathrm{min}^{-1}$. Solvent A was $\mathrm{H}_{2} \mathrm{O}$ with $0.1 \%$ formic acid and solvent $\mathrm{B}$ was acetonitrile containing $0.1 \%$ formic acid. The gradient program was: 0-3 min, linear gradient from 0-5\% B; 3-5 min, 5\% B; 5-50 min, linear gradient to 50\% B; 50-52 min, linear gradient to $80 \%$ B; 52-55 min, linear gradient to $90 \%$ B; 55-56 min, $90 \%$ $B$ in solvent A. MS/MS scans were acquired using an isolation width of $2 \mathrm{~m} / \mathrm{z}$, an activation time of $30 \mathrm{~ms}$, an activation $\mathrm{Q}$ of 0.250 , and $30 \%$ normalized collision energy using 1 microscan and ion time of 100 for each MS/MS scan. The mass-spectrometer was tuned prior to analysis using the synthetic peptide TpepK (AVAGKAGAR). Some parameters may have varied slightly from experiment to experiment, but typically the tune parameters were as follows: spray voltage of $2.0 \mathrm{KV}$, capillary temperature of $160^{\circ} \mathrm{C}$, capillary voltage of $60 \mathrm{~V}$, and tube lens of $130 \mathrm{~V}$. Tandem MS analysis was performed using data-dependent scanning in which one full MS spectrum, using a full mass range of 400-2000 amu, was followed by 3 MS/MS spectra. Wild-type and modified peptides were identified using the SEQUEST algorithm (59), and the SEQUEST Browser software (Thermo Electron, San Jose, CA) using the human subset of the NCBI database. In addition, lists of theoretical or Sequest identified unmodified peptides were created and each peptide was run through P-Mod software to check for possible 
chemical modifications (60). The candidate modifications found by software were verified by visual inspection of corresponding spectra.

\section{Generation of Mutant Human Topoisomerase lla Proteins}

Mutations in the topoisomerase II $\alpha$ PCR substrate were generated by cloning a SalI-KpnI fragment of YEpWob6 (61) that encoded the N-terminus of the human enzyme into pUC18. Site-directed mutagenesis was performed using the QuickChange II PCR system (Stratagene). The sequence of the forward and reverse primers used to generate the C170A mutation were GGAGCCAAATTGGCTAACATATTCAGTACCAAATTTACTGTGG and GAATATGTTAGCCAATTTGGCTCCATAGCCATTTCGACCACC, respectively. The sequence of the forward and reverse primers used to generate the C392A mutation were CTTTACAACCCAAGAGCTTTGGATCAACAGCCCAATTGAGTG and GATAAATTTTTCACTCAATTGGGCTGTTGATCCAAAGCTCTTGG, respectively. The sequence of the forward and reverse primers used to generate the $\mathrm{C} 405 \mathrm{~A}$ mutation were CAAAGCTGCCATTGGCGCTGGTATTGTAGAAAGCATAC and CAGTTTAGTATGCTTTCTACAATACCAGCGCCAATGGCAGC, respectively. The mutagenized codons are underlined. To generate the C392/405A double mutation, sequential rounds of PCR were performed using the primers to generate the C392A and C405A mutations as above. Mutations were verified by sequencing and SalI-KpnI fragments were cloned back into YEpWob6. Mutant human topoisomerase II $\alpha$ enzymes were purified as described above.

\section{Site-specific DNA Cleavage}

DNA sites cleaved by human topoisomerase II $\alpha$ were determined as described by O'Reilly and Kreuzer (62). A linear 4330 bp fragment (HindIII/EcoRI) of pBR322 plasmid DNA singly labeled with ${ }^{32} \mathrm{P}$ on the 5 '-terminus of the HindIII site was used as the cleavage substrate. Reaction mixtures contained $0.35 \mathrm{nM}$ DNA substrate and $60 \mathrm{nM}$ human topoisomerase II $\alpha$ in $50 \mu \mathrm{L}$ of cleavage buffer containing $1 \mathrm{mM}$ ATP. Assays were carried out in the absence of drug or in the presence of $12.5 \mu \mathrm{M}$ etoposide, $25 \mu \mathrm{M}$ benzoquinone or $100-500 \mu \mathrm{M}$ plumbagin. Reaction mixtures were incubated for $10 \mathrm{~min}$ at $37^{\circ} \mathrm{C}$. Cleavage intermediates were trapped by adding $5 \mu \mathrm{L}$ of $5 \%$ SDS followed by $3 \mu \mathrm{L}$ of $375 \mathrm{mM} \mathrm{NaEDTA}$, pH 8.0. Topoisomerase II $\alpha$ was digested with proteinase $\mathrm{K}(5 \mu \mathrm{L}$ of $0.8 \mathrm{mg} / \mathrm{mL})$ for $30 \mathrm{~min}$ at $45^{\circ} \mathrm{C}$. Reaction products were precipitated twice in ethanol, dried, and resuspended in $40 \%$ formamide, $8.4 \mathrm{mM}$ EDTA, $0.02 \%$ bromophenol blue, and $0.02 \%$ xylene cyanole FF. Samples were subjected to electrophoresis in a $6 \%$ sequencing gel. The gel was then fixed in $10 \%$ methanol/10\% acetic acid for $5 \mathrm{~min}$, dried, and DNA cleavage products were analyzed on a Bio-Rad Molecular Imager FX.

\section{Cleavage of Plasmid DNA}

DNA cleavage reactions were carried out using the procedure of Fortune and Osheroff (63). Unless stated otherwise, assay mixtures contained $135 \mathrm{nM}$ wild-type or mutant topoisomerase II $\alpha$ and $10 \mathrm{nM}$ negatively supercoiled pBR322 DNA in a total of $20 \mu \mathrm{L}$ of cleavage buffer that contained 0-200 $\mu \mathrm{M}$ benzoquinone, $4^{\prime} \mathrm{Cl}-2,5 \mathrm{pQ}$, or etoposide. DNA cleavage was initiated by shifting mixtures to $37^{\circ} \mathrm{C}$ and samples were incubated for 6 min to establish DNA cleavagereligation equilibria. Enzyme-DNA cleavage intermediates were trapped by adding $2 \mu \mathrm{L}$ of $5 \%$ SDS and $1 \mu \mathrm{L}$ of $375 \mathrm{mM}$ EDTA, pH 8.0. Proteinase $\mathrm{K}$ was added $(2 \mu \mathrm{L}$ of $0.8 \mathrm{mg} / \mathrm{mL}$ ) and reaction mixtures were incubated for $30 \mathrm{~min}$ at $45^{\circ} \mathrm{C}$ to digest the topoisomerase II $\alpha$. Samples were mixed with $2 \mu \mathrm{L}$ of $60 \%$ sucrose in $10 \mathrm{mM}$ Tris-HCl, pH 7.9, $0.5 \%$ bromophenol blue, and $0.5 \%$ xylene cyanol $\mathrm{FF}$, heated for $15 \mathrm{~min}$ at $45^{\circ} \mathrm{C}$, and subjected to electrophoresis in $1 \%$ agarose gels in $40 \mathrm{mM}$ Tris-acetate, $\mathrm{pH} 8.3,2 \mathrm{mM}$ EDTA that contained $0.5 \mu \mathrm{g} / \mathrm{mL}$ ethidium bromide. DNA cleavage was monitored by the conversion of negatively supercoiled 
plasmid DNA to linear molecules. DNA bands were visualized by ultraviolet light and quantified using an Alpha Innotech digital imaging system.

\section{DNA Religation}

The DNA religation reaction of human topoisomerase II $\alpha$ was monitored according to the procedure of Byl et al. (64). Topoisomerase II $\alpha$ DNA cleavage/religation equilibria were established using a plasmid substrate as described in the preceding section in the absence or presence of $100 \mu \mathrm{M}$ benzoquinone. Religation was initiated by shifting reaction mixtures from $37{ }^{\circ} \mathrm{C}$ to $0{ }^{\circ} \mathrm{C}$, and reactions were stopped by the addition of $2 \mu \mathrm{L}$ of $5 \%$ SDS followed by 1 $\mu \mathrm{L}$ of $375 \mathrm{mM}$ NaEDTA, pH 8.0. Samples were processed and analyzed as described above for topoisomerase II $\alpha$ cleavage reactions.

\section{DNA Binding}

Topoisomerase II $\alpha$ binding to linear DNA substrates was assessed using a nitrocellulose filterbinding assay. Either linearized pBR322 DNA (described above) or a 50-mer oligonucleotide was used. The 50-mer oligonucleotide containing a single topoisomerase II cleavage site and its complementary strand were prepared on an Applied Biosystems DNA synthesizer. The sequences of the top and bottom strands were 5'TTGGTATCTGCGCTCTGCTGAAGCC $\downarrow$ AGTTACCTTCGGAAAAAGAGTTGGT-3' and 5'-ACCAACTCTTTTTCCGAAGGT $\downarrow$ AACTGGCTTCAGCA-

GAGCGCAGATACCAA-3', respectively. This substrate contains a single topoisomerase II cleavage site (65) that is denoted by the arrows. Wild-type or mutant topoisomerase II $\alpha$ was incubated with benzoquinone for $5 \mathrm{~min}$ at $37^{\circ} \mathrm{C}$ in $15 \mu \mathrm{L}$ of DNA binding buffer $(10 \mathrm{mM}$ Tris$\mathrm{HCl}, \mathrm{pH} 7.9,30 \mathrm{mM} \mathrm{KCl}, 0.1 \mathrm{mM} \mathrm{NaEDTA}$, and $2.5 \%$ glycerol). Binding was initiated by adding DNA in $5 \mu \mathrm{L}$ of binding buffer and samples were incubated at $37^{\circ} \mathrm{C}$ for $6 \mathrm{~min}$. The final concentrations of topoisomerase II $\alpha$, DNA, and benzoquinone in the binding mixtures were $400 \mathrm{nM}, 5 \mathrm{nM}$, and $100 \mu \mathrm{M}$, respectively. Nitrocellulose membranes $(0.45 \mu \mathrm{m} \mathrm{HA}$, Millipore) were prepared by incubation in DNA binding buffer for $10 \mathrm{~min}$. Samples were applied to the membranes and filtered in vacuo. Membranes were washed 3 times with $1 \mathrm{~mL}$ of DNA binding buffer, dried, and submerged in $8 \mathrm{~mL}$ of scintillation fluid (Econo-Safe, Research Products International). Radioactivity remaining on the membranes was quantified using a Beckman LS 5000 TD Scintillation Counter.

Assays that monitored binding to a plasmid substrate were carried out according to the procedure of Fortune and Osheroff (66). Reaction mixtures contained $400 \mathrm{nM}$ enzyme and 100 $\mu \mathrm{M}$ benzoquinone in $15 \mu \mathrm{L}$ of binding buffer. Samples were incubated for 5 min at $37^{\circ} \mathrm{C}$. Binding was initiated by adding DNA in $5 \mu \mathrm{L}$ of binding buffer and samples were incubated for $6 \mathrm{~min}$ at $37^{\circ} \mathrm{C}$. The concentrations of topoisomerase II $\alpha$, DNA, and benzoquinone in the final mixtures were $400 \mathrm{nM}, 5 \mathrm{nM}$, and $100 \mu \mathrm{M}$, respectively. Samples were loaded directly

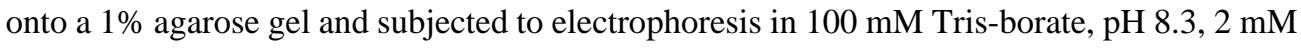
EDTA. Gels were stained for $30 \mathrm{~min}$ with $0.5 \mu \mathrm{g} / \mathrm{mL}$ ethidium bromide and samples were analyzed as described above.

\section{Protein Clamp Closing}

Filter binding assays were used to analyze the salt-stable closed-clamp of topoisomerase II $\alpha$ $(39,67)$. Briefly, $5 \mathrm{nM}$ wild-type or mutant human topoisomerase II $\alpha$ and $2 \mathrm{nM}$ pBR322 were incubated for $4 \mathrm{~min}$ at $37^{\circ} \mathrm{C}$ in a total of $90 \mu \mathrm{L}$ of clamp closing buffer $(50 \mathrm{mM}$ Tris- $\mathrm{HCl}, \mathrm{pH}$ $8.0,100 \mathrm{mM} \mathrm{KCl}, 1 \mathrm{mM}$ EDTA, $8 \mathrm{mM} \mathrm{MgCl}_{2}$ ). Benzoquinone (10 $\mu \mathrm{L}$ of $1 \mathrm{mM}$ in $10 \% \mathrm{DMSO}$ ) or an equivalent amount of solvent was added, and mixtures were incubated for an additional 6 min at $37^{\circ} \mathrm{C}$. 
Binding mixtures were loaded onto glass fiber filters (Millipore) pre-incubated in clamp closing buffer, and filtered in vacuo. Filters were washed 3 times with clamp closing buffer (low salt wash), followed by 3 washes with clamp closing buffer that contained $1 \mathrm{M} \mathrm{NaCl}$ (high salt wash), and 3 washes with $10 \mathrm{mM}$ Tris- $\mathrm{HCl}, \mathrm{pH}$ 8.0, 1 mM EDTA, and 0.5\% SDS. DNA was precipitated with isopropanol and loaded onto a $1 \%$ agarose gel in $40 \mathrm{mM}$ Tris-acetate, $\mathrm{pH} 8.3$, $2 \mathrm{mM}$ EDTA that contained $0.5 \mu \mathrm{g} / \mathrm{mL}$ ethidium bromide. DNA was visualized as described above.

\section{Protein Crosslinking}

The ability of quinones to crosslink the protomer subunits of human topoisomerase II $\alpha$ was assessed using SDS polyacrylamide gels. Crosslinking mixtures contained $135 \mathrm{nM}$ wild-type or mutant topoisomerase II $\alpha$ in a total of $60 \mu \mathrm{L}$ of cleavage buffer. The enzyme was incubated for $0-4 \mathrm{~min}$ at $37^{\circ} \mathrm{C}$ in the presence of $100 \mu \mathrm{M}$ benzoquinone. Reactions were quenched by the addition of $6 \mu \mathrm{L}$ of $5 \mathrm{mM}$ DTT followed by an additional $2 \mathrm{~min}$ incubation at $37^{\circ} \mathrm{C}$. Samples were precipitated with TCA and resuspended in $10 \mu \mathrm{L}$ of $\mathrm{H}_{2} \mathrm{O}$. Laemmli buffer $(10 \mu \mathrm{L}$, BioRad) was added and samples were subject to electrophoresis in a 7.5\% denaturing acrylamide gel (Bio-Rad) at $200 \mathrm{v}$ for $1 \mathrm{hr}$. The protein was visualized by coomassie staining.

\section{RESULTS}

\section{Identification of Cysteine Residues in Human Topoisomerase lla that are Adducted by Quinones}

Quinones are unique among topoisomerase II poisons in that their actions require adduction to the enzyme (35-39,53). It is not known how this covalent modification increases levels of cleavage complexes and it is possible that quinones affect enzyme activity by more than one process. Religation experiments suggest that these compounds function at least in part by impairing the ability of topoisomerase II to rejoin cleaved DNA termini (36-39). In addition, quinones block the $\mathrm{N}$-terminal gate of the protein, thereby increasing the concentration of DNA associated with topoisomerase II by trapping the substrate in a non-covalent complex (39). Molecular sizing experiments suggest that quinones block the $\mathrm{N}$-terminal gate by crosslinking the two protomer subunits of topoisomerase II $\alpha$ (39).

In an effort to further dissect the mechanistic basis for the actions of quinones as topoisomerase II poisons, amino acid residues in human topoisomerase II $\alpha$ that are covalently modified by these compounds were identified by mass spectrometry. Initial attempts utilized benzoquinone as the modification agent. Unfortunately, no individual amino acid residues were identified in these experiments. This is most likely due to the ability of benzoquinone to crosslink multiple residues in the protein (53).

To overcome this technical difficulty, plumbagin, which has only a single reactive site, was employed (Figure 1). Plumbagin is a topoisomerase II poison, however, it is at least 10-fold less potent than benzoquinone (Figure 1). In addition, the compound does not effectively block the N-terminal gate of the enzyme (Figure 1) and does not crosslink the protomer subunits (39). These data support the hypothesis that multiple processes contribute to the increase in cleavage complexes by quinone-based topoisomerase II poisons.

As determined by LC-MS/MS analysis of tryptic and chymotryptic peptides derived from human topoisomerase II $\alpha$, four cysteine residues were adducted by plumbagin, cys170, cys392, cys 405 , and cys $455^{2}$. Representative spectra are shown in the supporting Figure S1A-D.

Modeling studies based on the structure of yeast topoisomerase II place cys170, cys 392 cys 405 in the N-terminal domain and cys 455 in the B'-subdomain of the catalytic core of the enzyme $(68,69)$ (Figure 2). As determined in a previous study, all of these residues exist in the protein 
as free sulfhydryls (i.e., not part of a disulfide bridge) with the exception of cys455, which is free only $10-15 \%$ of the time (70).

\section{DNA Cleavage Mediated by Mutant Human Topoisomerase lla Enzymes}

In order to assess the contributions of the above four cysteine residues to the actions of quinones as topoisomerase II poisons, each of the residues was individually mutated to an alanine residue and the resulting mutant enzymes (top $2 \alpha \mathrm{C} 170 \mathrm{~A}$, top $2 \alpha \mathrm{C} 392 \mathrm{~A}$, top $2 \alpha \mathrm{C} 405 \mathrm{~A}$, and top $2 \alpha \mathrm{C} 455 \mathrm{~A}$, respectively) were purified and characterized. With the exception of top $2 \alpha \mathrm{C} 455 \mathrm{~A}$, all of the mutant enzymes displayed wild-type DNA cleavage activity in the absence of topoisomerase II poisons (Figure $3 \mathrm{~A}$ ). Top $2 \alpha \mathrm{C} 455 \mathrm{~A}$ exhibited a cleavage activity that was $\sim 50 \%$ higher than wild-type (not shown). Since the basal properties of this mutant enzyme were altered, it was not utilized further in the present study. It should be noted, however, that top $2 \alpha \mathrm{C} 455 \mathrm{~A}$ showed no resistance toward quinones (not shown).

To further analyze the properties of top $2 \alpha \mathrm{C} 170 \mathrm{~A}$, top $2 \alpha \mathrm{C} 392 \mathrm{~A}$, and top $2 \alpha \mathrm{C} 405 \mathrm{~A}$, the sensitivity of these mutant enzymes topoisomerase II poisons was determined. Etoposide, a classic topoisomerase II poison, as well as benzoquinone and the PCB metabolite 4' $\mathrm{Cl}-2,5 \mathrm{pQ}$, two quinone-based topoisomerase II poisons, were utilized for these experiments. As shown in Figure 3B, all displayed wild-type sensitivity to the anticancer drug etoposide. In contrast, two of the mutant enzymes, top $2 \alpha \mathrm{C} 392 \mathrm{~A}$ and top $2 \alpha \mathrm{C} 405 \mathrm{~A}$, were less responsive to benzoquinone (Figure 3C) and 4' $\mathrm{Cl}-2,5 \mathrm{pQ}$ (Figure 3D) than was wild-type topoisomerase II $\alpha$. The decreased sensitivity did not appear to be due to a reduced affinity for quinone, because at saturating levels of benzoquinone or 4'Cl-2,5pQ, levels of DNA cleaved by the mutant enzymes were only one-half of those observed with the parental enzyme.

The finding that mutation of cys 392 or cys 405 causes partial resistance toward quinones can be explained by two possibilities. For example, one residue may be involved in the inhibition of DNA religation while the other may be involved in blocking the N-terminal gate. If this were the case, an enzyme that carries alanine residues at both positions (top2 $\alpha \mathrm{C} 392 / 405 \mathrm{~A}$ ) should display enhanced resistance over either singly-mutated enzyme.

Alternatively, adduction of these residues by quinones may enhance topoisomerase II $\alpha$ mediated DNA cleavage by the same mechanism (religation or the N-terminal gate). However, it is necessary to modify both residues in order to observe an effect. If this were the case, the doubly-mutated enzyme should display a sensitivity to quinones that is similar to that of either singly-mutated enzyme.

To address this mechanistic issue, top $2 \alpha \mathrm{C} 392 / 405 \mathrm{~A}$ was generated and isolated. Like top $2 \alpha \mathrm{C} 392 \mathrm{~A}$ and top $2 \alpha \mathrm{C} 405 \mathrm{~A}$, the doubly-mutated enzyme exhibited wild-type DNA cleavage activity in the absence (Figure 3A) or presence (Figure 3B) of etoposide, but displayed one-half of the sensitivity to either benzoquinone (Figure 3C) or 4'Cl-2,5pQ (Figure 3D). These findings suggest that quinone adduction of cys392 and cys 405 enhances topoisomerase II $\alpha$-mediated DNA cleavage as part of the same process.

Finally, two additional cysteine residues, cys 216 and cys 300 , have been shown to exist in the protein as free sulfhydryls (70). Even though they were not identified as sites of quinone

\footnotetext{
${ }^{2}$ Human topoisomerase II $\alpha$ contains 13 cysteine residues. Two of these residues, cys 300 and cys 862 , were not covered by the digests used in the present study. The N-terminal peptide also was not identified by mass spectral analysis. Adducted cys 170 and cys 392 were identified in two independent tryptic digests of topoisomerase II $\alpha$. Adducted cys 455 was identified in one of the tryptic digests and two independent chymotryptic digests. Adducted cys 405 was identified in only one of the chymotryptic digests. However, since this latter residue is known to exist as a free sulfhydryl in the protein and is solvent accessible, the decision was made to continue studies with this residue as a site of quinone modification.
} 
adduction in the present work, top $2 \alpha \mathrm{C} 216 \mathrm{~A}$ and top $2 \alpha \mathrm{C} 300 \mathrm{~A}$ were generated and analyzed. Neither enzyme displayed any resistance to benzoquinone or 4'Cl-2,5pQ (not shown).

\section{Effects of Benzoquinone on DNA Religation Mediated by Mutant Human Topoisomerase lla Enzymes}

To further examine the role of cys392 and cys 405 in facilitating the actions of quinones against human topoisomerase II $\alpha$, the abilities of wild-type enzyme, top $2 \alpha \mathrm{C} 170 \mathrm{~A}$ top $2 \alpha \mathrm{C} 392 \mathrm{~A}$, top2 $\alpha \mathrm{C} 405 \mathrm{~A}$, and top2 $\alpha \mathrm{C} 392 / 405 \mathrm{~A}$ to religate cleaved DNA in the absence or presence of benzoquinone was determined (Figure 4). In the absence of the quinone, all of the enzymes religated DNA to a similar extent ( $\sim 50 \%$ ligation was observed in $10 \mathrm{~s})$. However, in the presence of benzoquinone, top $2 \alpha \mathrm{C} 392 \mathrm{~A}$, top $2 \alpha \mathrm{C} 405 \mathrm{~A}$, and top $2 \alpha \mathrm{C} 392 / 405 \mathrm{~A}$ exhibited faster rates of religation ( $40 \%$ ligation in $10 \mathrm{~s}$ ) as compared to either wild-type topoisomerase II $\alpha$ or top $2 \alpha \mathrm{C} 170 \mathrm{~A}$ ( $\sim 20 \%$ ligation in $10 \mathrm{~s})$. These findings support the conclusions of the preceding section and strongly suggest that adduction of cys 392 and cys 405 by quinones increases levels of DNA cleavage complexes by inhibiting the ability of the enzyme to religate cleaved nucleic acid substrates.

\section{Ability of Benzoquinone to Block the N-terminal Gate of Mutant Human Topoisomerase Ila Enzymes}

As discussed above, quinones that are strong topoisomerase II poisons contain multiple electrophilic carbons (i.e., sites of adduction) and block the N-terminal gate of human topoisomerase II $\alpha$ by crosslinking the two protomers of the enzyme (39,53). This action has no direct effect on the DNA cleavage-religation equilibrium of the enzyme. However, since it traps the non-covalent protein-DNA complex, it increases levels of scission by raising the concentration of DNA in the active site of topoisomerase II. Therefore, to determine whether any of the cysteine residues identified by mass spectrometry as sites of quinone adduction in topoisomerase II $\alpha$ are involved in blocking the N-terminal gate of the enzyme, DNA binding, protein clamp closing, and protomer crosslinking experiments were performed.

Initial studies examined the ability of quinone-treated enzymes to bind circular and linear forms of DNA. As seen in Figure 5, treatment of wild-type topoisomerase II $\alpha$ with benzoquinone prior to the addition of DNA differentially affects the ability of the enzyme to bind these DNA substrates. By blocking the $\mathrm{N}$-terminal gate of topoisomerase II $\alpha$, quinones impair the ability of circular DNA to diffuse into the active site in the central annulus of the protein. This action decreased levels of circular DNA binding to $~ 30 \%$ of the levels observed in the absence of quinone. In contrast, linear forms of DNA, especially short oligonucleotides (double-stranded 50-mer), are able to enter the "closed-clamp" form of the enzyme and bind to the active site ( $\sim 80 \%$ and $100 \%$ binding, respectively, as compared to parallel "no quinone" controls). DNA binding results for quinone-treated top $2 \alpha \mathrm{C} 170 \mathrm{~A}$, top $2 \alpha \mathrm{C} 392 \mathrm{~A}$, top $2 \alpha \mathrm{C} 405 \mathrm{~A}$, and top2 $\alpha \mathrm{C} 392 / 405 \mathrm{~A}$ were nearly identical to those observed for the wild-type enzyme (Figure 5).

The second set of experiments utilized a "clamp closing" assay. In these experiments, the enzyme was incubated with circular DNA substrates prior to the addition of benzoquinone. Blocking the $\mathrm{N}$-terminal gate traps the circular substrate in the central annulus of topoisomerase $\mathrm{II} \alpha$, generating a non-covalent protein-DNA complex that is stable in $1 \mathrm{M} \mathrm{NaCl}$ (67).

Benzoquinone treatment increased the concentration of salt-stable protein-DNA complexes $\sim 4$-fold (from $\sim 4.5 \%$ to $\sim 17 \%$ of the total DNA) when wild-type topoisomerase II $\alpha$ was employed (Figure 6). Once again, similar results were observed for all of mutant enzymes. Levels of salt-stable complexes formed with top $2 \alpha \mathrm{C} 392 \mathrm{~A}$, top $2 \alpha \mathrm{C} 405 \mathrm{~A}$, and top $2 \alpha \mathrm{C} 392 / 405 \mathrm{~A}$ were slightly lower ( 13-14\% of the total DNA) than seen with wild-type enzyme in the presence of benzoquinone. However, levels of salt-stable protein complexes formed with these enzymes also were lower ( 3.2-3.6\% of the total DNA) in the absence of quinone (Figure 6). 
The third set of experiments examined the ability of benzoquinone to crosslink the two protomer subunits of human topoisomerase II $\alpha$. Exposure of the enzyme to quinones efficiently crosslinks the two protomer subunits of the protein homodimer (39). This event is monitored by gel electrophoresis under denaturing conditions and is characterized by the loss of the $\sim 170$ $\mathrm{kDa}$ protomer and the subsequent generation of a new protein species with an apparent molecular mass of $\sim 330 \mathrm{kDa}$. As seen in Figure 7, treatment of wild-type topoisomerase II $\alpha$ as well as the mutant enzymes with benzoquinone resulted in a rapid loss of protein monomer. The half-life for protomer crosslinking ( $\sim 15 \mathrm{~s})$ was similar for all of the enzymes examined. To address the possibility that all three cysteine residues (cys170, cys392, and cys405) are involved in crosslinking with only one being required at any given time, a triple mutant of topoisomerase II $\alpha$ (top $2 \alpha \mathrm{C} 170 / 392 / 405 \mathrm{~A}$ ) was generated. The half-life for protomer crosslinking of this enzyme was similar to that of the double top $2 \alpha \mathrm{C} 392 / 405 \mathrm{~A}$ mutant (data not shown).

Taken together, the experiments described above provide strong evidence that cys 170 , cys 392 , and cys 405 are not required for quinones to block the $\mathrm{N}$-terminal of topoisomerase II $\alpha$ or crosslink the two protomer subunits of the protein. Thus, the adduction of cys 392 and cys 405 by benzoquinone appears to enhance DNA scission mediated by topoisomerase II $\alpha$ primarily by inhibiting the ability of the enzyme to religate cleaved nucleic acid molecules.

\section{DISCUSSION}

A variety of drug-related and environmental quinone-based metabolites are potent topoisomerase II poisons. These compounds act by adducting the protein, and previous studies suggest that they increase levels of enzyme-DNA cleavage complexes by at least two potentially independent mechanisms (36-39). Quinones act directly on the DNA cleavagereligation equilibrium of topoisomerase II by inhibiting rates of religation. Alternatively, they block the $\mathrm{N}$-terminal gate of the protein by crosslinking its two protomer subunits, and thereby raise levels of cleavage complexes by increasing the local concentration of DNA in the active site of the enzyme. It is not known whether these two effects result from quinone adduction to the same amino acid residue(s) in topoisomerase II $\alpha$ or whether they are mediated by modification of separate residues.

Although anticancer drugs and other classic topoisomerase II poisons function at the active site of the enzyme $(4,15,17-19,71)$, sites at which quinone-based poisons adduct the protein are not known. Therefore, the present study identified amino acid residues that are modified by quinones and determined their role in the actions of these compounds as topoisomerase II poisons. Four cysteine residues were identified by mass spectrometry as sites of quinone adduction: cys170, cys392, cys405, and cys455. Mutations (cys->ala) were individually generated at each of these positions. Only mutations at cys 392 or cys 405 resulted in enzymes with reduced sensitivity to benzoquinone or 4 ' $\mathrm{Cl}-2,5 \mathrm{pQ}$. Top $2 \alpha \mathrm{C} 392 \mathrm{~A}$, top $2 \alpha \mathrm{C} 405 \mathrm{~A}$, and the double mutant top $2 \alpha \mathrm{C} 392 / 405 \mathrm{~A}$ all displayed $\sim 50 \%$ resistance to these compounds.

Furthermore, top $2 \alpha \mathrm{C} 392 / 405 \mathrm{~A}$ (the only mutant enzyme tested) was $\sim 2$ - to 4 -fold resistant to plumbagin (data not shown). Results of DNA religation and binding studies, together with protein clamp closing and crosslinking experiments, strongly suggest that adduction of cys 392 and cys 405 increases levels of topoisomerase II $\alpha$-mediated DNA cleavage primarily by inhibiting the ability of the enzyme to reseal nucleic acid breaks.

Studies with Top $2 \alpha C 392 \mathrm{~A}$, top $2 \alpha \mathrm{C} 405 \mathrm{~A}$, and the double mutant top $2 \alpha \mathrm{C} 392 / 405 \mathrm{~A}$ indicate that cys 392 and cys 405 both are required to observe inhibition of DNA religation by quinones. Given the close proximity of these two residues (Figure 2), an intriguing possibility is that quinones such as benzoquinone act by forming an intra-protomer crosslink between cys 392 
and cys405. This could help explain why mono-adducting quinones, such as plumbagin, are weak topoisomerase II poisons. Future structural studies will be required to explore this issue.

None of the cysteine residues identified in the present study appear to be involved in quinoneblocking of the $\mathrm{N}$-terminal gate or protomer crosslinking. This finding implies that the above affect and the inhibition of DNA religation by quinones are mediated by adduction to separate amino acid residues. As monitored by mass spectrometry, eleven of the thirteen cysteine residues in human topoisomerase II $\alpha$ were covered by the tryptic digests employed. Of the two that were not covered, cys300 and cys862, only the former is in the N-terminal domain and mutagenesis studies indicated that elimination of cys 300 had no effect on quinone sensitivity. It is notable that the $\mathrm{N}$-terminal peptide of topoisomerase II $\alpha$ was not covered in our mass spectrometry study. In light of the fact that $\mathrm{N}$-terminal amines often display high reactivity, it is possible that this residue is involved in crosslinking the protomer subunits of the enzyme. High resolution mass spectrometry studies are currently underway to address this possibility.

In conclusion, quinones are topoisomerase II poisons that act by adducting the enzyme. Results of the present study indicate that adduction of cys 392 and cys 405 is important for the actions of quinones and increases levels of enzyme-DNA cleavage complexes primarily by inhibiting DNA religation.

\section{Supplementary Material}

Refer to Web version on PubMed Central for supplementary material.

\section{Acknowledgments}

We are grateful to Dr. Hans J. Lehmler, University of Iowa for the generous gift of 4'Cl-2,5pQ, and to Omari J. Bandele and Joseph E. Deweese for critical reading of the manuscript.

\section{REFERENCES}

1. Wang JC. DNA Topoisomerases. Annu. Rev. Biochem 1996;65:635-692. [PubMed: 8811192]

2. Nitiss JL. Investigating the biological functions of DNA topoisomerases in eukaryotic cells. Biochim. Biophys. Acta 1998;1400:63-81. [PubMed: 9748506]

3. Wang JC. Moving one DNA double helix through another by a type II DNA topoismerase: the story of a simple molecular machine. Quart. Rev. Biophys 1998;31:107-144.

4. Fortune JM, Osheroff N. Topoisomerase II as a target for anticancer drugs: when enzymes stop being nice. Prog. Nucleic Acid. Res. Mol. Biol 2000;64:221-253. [PubMed: 10697411]

5. Champoux JJ. DNA topoisomerases: structure, function, and mechanism. Annu. Rev. Biochem 2001;70:369-413. [PubMed: 11395412]

6. Wang JC. Cellular roles of DNA topoisomerases: a molecular perspective. Nat. Rev. Mol. Cell. Biol 2002;3:430-440. [PubMed: 12042765]

7. Velez-Cruz, R.; Osheroff, N. DNA Topoisomerases: Type II. In: Lennarz, W.; Lane, MD., editors. Encyclopedia of Molecular Biology. Elsevier Science; San Diego: 2004. p. 806-811.

8. Sander M, Hsieh T. Double strand DNA cleavage by type II DNA topoisomerase from Drosophila melanogaster. J. Biol. Chem 1983;258:8421-8428. [PubMed: 6305984]

9. Liu LF, Rowe TC, Yang L, Tewey KM, Chen GL. Cleavage of DNA by mammalian DNA topoisomerase II. J. Biol. Chem 1983;258:15365-15370. [PubMed: 6317692]

10. Zechiedrich EL, Christiansen K, Andersen AH, Westergaard O, Osheroff N. Double-stranded DNA cleavage/religation reaction of eukaryotic topoisomerase II: evidence for a nicked DNA intermediate. Biochemistry 1989;28:6229-6236. [PubMed: 2551367]

11. Kaufmann SH. Cell death induced by topoisomerase-targeted drugs: more questions than answers. Biochim. Biophys. Acta 1998;1400:195-211. [PubMed: 9748575] 
12. Kaufmann SH, Gore SD, Miller CB, Jones RJ, Zwelling LA, Schneider E, Burke PJ, Karp JE. Topoisomerase II and the response to antileukemic therapy. Leukemia Lymph 1998;29:217-237.

13. Rowley JD. The critical role of chromosome translocations in human leukemias. Ann. Rev. Genet 1998;32:495-519. [PubMed: 9928489]

14. Felix CA. Secondary leukemias induced by topoisomerase-targeted drugs. Biochim. Biophys. Acta 1998;1400:233-255. [PubMed: 9748598]

15. Wilstermann AM, Osheroff N. Stabilization of eukaryotic topoisomerase IIDNA cleavage complexes. Curr. Top. Med. Chem 2003;3:321-338. [PubMed: 12570766]

16. Sordet O, Khan QA, Kohn KW, Pommier Y. Apoptosis induced by topoisomerase inhibitors. Curr. Med. Chem. Anti-Canc. Agents 2003;3:271-290.

17. Li TK, Liu LF. Tumor cell death induced by topoisomerase-targeting drugs. Annu. Rev. Pharmacol. Toxicol 2001;41:53-77. [PubMed: 11264450]

18. Walker JV, Nitiss JL. DNA topoisomerase II as a target for cancer chemotherapy. Cancer Invest 2002;20:570-589. [PubMed: 12094551]

19. Baldwin EL, Osheroff N. Etoposide, topoisomerase II and cancer. Curr. Med. Chem. Anti-Canc. Agents 2005;5:363-372.

20. Adlercreutz H, Markkanen H, Watanabe S. Plasma concentrations of phytooestrogens in Japanese men. Lancet 1993;342:1209-1210. [PubMed: 7901532]

21. Lamartiniere CA. Protection against breast cancer with genistein: a component of soy. Am. J. Clin. Nutr 2000;71:1705S-1709S. [PubMed: 10837323]

22. Sarkar FH, Adsule S, Padhye S, Kulkarni S, Li Y. The role of genistein and synthetic derivatives of isoflavone in cancer prevention and therapy. Mini Rev. Med. Chem 2006;6:401-407. [PubMed: 16613577]

23. Siddiqui IA, Adhami VM, Saleem M, Mukhtar H. Beneficial effects of tea and its polyphenols against prostate cancer. Mol. Nutr. Food Res 2006;50:130-143. [PubMed: 16425281]

24. DeVore R, Whitlock J, Hainsworth T, Johnson D. Therapy-related acute nonlymphocytic leukemia with monocytic features and rearrangement of chromosome 11q. Annals of Internal Medicine 1989;110:740-742. [PubMed: 2648930]

25. Ratain MJ, Rowley JD. Therapy-related acute myeloid leukemia secondary to inhibitors of topoisomerase II: from the bedside to the target genes. Annals Oncol 1992;3:107-111.

26. Smith MA, Rubinstein L, Anderson JR, Arthur D, Catalano PJ, Freidlin B, Heyn R, Khayat A, Krailo M, Land VJ, Miser J, Shuster J, Vena D. Secondary leukemia or myelodysplastic syndrome after treatment with epipodophyllotoxins. Journal of Clinical Oncology 1999;17:569-577. [PubMed: 10080601]

27. Pui CH, Relling MV. Topoisomerase II inhibitor-related acute myeloid leukaemia. Br. J. Haematol 2000;109:13-23. [PubMed: 10848777]

28. Felix CA. Leukemias related to treatment with DNA topoisomerase II inhibitors. Medical \& Pediatric Oncology 2001;36:525-535. [PubMed: 11340607]

29. Leone G, Voso MT, Sica S, Morosetti R, Pagano L. Therapy related leukemias: susceptibility, prevention and treatment. Leuk. Lymphoma 2001;41:255-276. [PubMed: 11378539]

30. Ross JA, Potter JD, Robison LL. Infant leukemia, topoisomerase II inhibitors, and the MLL gene. Journal of the National Cancer Institute 1994;86:1678-1680. [PubMed: 7966394]

31. Ross JA, Potter JD, Reaman GH, Pendergrass TW, Robison LL. Maternal exposure to potential inhibitors of DNA topoisomerase II and infant leukemia (United States): a report from the Children's Cancer Group. Cancer causes \& control : CCC 1996;7:581-590.

32. Ross JA. Dietary flavonoids and the MLL gene: A pathway to infant leukemia? Proc. Natl. Acad. Sci. U S A 2000;97:4411-4413. [PubMed: 10781030]

33. Strick R, Strissel PL, Borgers S, Smith SL, Rowley JD. Dietary bioflavonoids induce cleavage in the $M L L$ gene and may contribute to infant leukemia. Proc. Natl. Acad. Sci. U S A 2000;97:4790-4795. [PubMed: 10758153]

34. Spector LG, Xie Y, Robison LL, Heerema NA, Hilden JM, Lange B, Felix CA, Davies SM, Slavin J, Potter JD, Blair CK, Reaman GH, Ross JA. Maternal diet and infant leukemia: the DNA 
topoisomerase II inhibitor hypothesis: a report from the children's oncology group. Cancer Epidemiol. Biomarkers Prev 2005;14:651-655. [PubMed: 15767345]

35. Wang H, Mao Y, Chen AY, Zhou N, LaVoie EJ, Liu LF. Stimulation of topoisomerase II-mediated DNA damage via a mechanism involving protein thiolation. Biochemistry 2001;40:3316-3323. [PubMed: 11258951]

36. Bender RP, Lindsey RH Jr. Burden DA, Osheroff N. N-acetyl-pbenzoquinone imine, the toxic metabolite of acetaminophen, is a topoisomerase II poison. Biochemistry 2004;43:3731-3739. [PubMed: 15035644]

37. Lindsey RH Jr. Bromberg KD, Felix CA, Osheroff N. 1,4-Benzoquinone is a topoisomerase II poison. Biochemistry 2004;43:7563-7574. [PubMed: 15182198]

38. Lindsey RH Jr. Bender RP, Osheroff N. Effects of benzene metabolites on DNA cleavage mediated by human topoisomerase II alpha: 1,4-hydroquinone is a topoisomerase II poison. Chem. Res. Toxicol 2005;18:761-770. [PubMed: 15833037]

39. Bender RP, Lehmler HJ, Robertson LW, Ludewig G, Osheroff N. Polychlorinated Biphenyl Quinone Metabolites Poison Human Topoisomerase IIalpha: Altering Enzyme Function by Blocking the NTerminal Protein Gate. Biochemistry 2006;45:10140-10152. [PubMed: 16906772]

40. Ludewig G, Dogra S, Glatt H. Genotoxicity of 1,4-benzoquinone and 1,4-naphthoquinone in relation to effects on glutathione and NAD(P)H levels in V79 cells. Environ. Health Perspect 1989;82:223228. [PubMed: 2792044]

41. Smith MT. The mechanism of benzene-induced leukemia: a hypothesis and speculations on the causes of leukemia. Environ. Health Perspect 1996;104(Sup 6):1219-1225. [PubMed: 9118896]

42. Sze CC, Shi CY, Ong CN. Cytotoxicity and DNA strand breaks induced by benzene and its metabolites in Chinese hamster ovary cells. J. Appl. Toxicol 1996;16:259-264. [PubMed: 8818868]

43. Nakayama A, Koyoshi S, Morisawa S, Yagi T. Comparison of the mutations induced by pbenzoquinone, a benzene metabolite, in human and mouse cells. Mutat. Res 2000;470:147-153. [PubMed: 11027969]

44. Ludewig, G. Cancer Initiation by PCBs.. In: Robertson, LW.; Hansen, LG., editors. PCBs, Recent Advances in Environmental Toxicology and Health Effects. University Press of Kentucky; Lexington, KY: 2001. p. 337-354.

45. Wiemels JL, Pagnamenta A, Taylor GM, Eden OB, Alexander FE, Greaves MF. A lack of a functional $\mathrm{NAD}(\mathrm{P}) \mathrm{H}$ :quinone oxidoreductase allele is selectively associated with pediatric leukemias that have MLL fusions. United Kingdom Childhood Cancer Study Investigators. Cancer Res 1999;59:40954099. [PubMed: 10463613]

46. Larson RA, Wang Y, Banerjee M, Wiemels J, Hartford C, Le Beau MM, Smith MT. Prevalence of the inactivating 609C--> T polymorphism in the $\mathrm{NAD}(\mathrm{P}) \mathrm{H}$ :quinone oxidoreductase (NQO1) gene in patients with primary and therapy-related myeloid leukemia. Blood 1999;94:803-807. [PubMed: 10397748]

47. Smith MT. Benzene, NQO1, and genetic susceptibility to cancer. Proc. Natl. Acad. Sci. U S A 1999;96:7624-7626. [PubMed: 10393869]

48. Smith MT, Wang Y, Kane E, Rollinson S, Wiemels JL, Roman E, Roddam P, Cartwright R, Morgan G. Low NAD(P)H:quinone oxidoreductase 1 activity is associated with increased risk of acute leukemia in adults. Blood 2001;97:1422-1426. [PubMed: 11222389]

49. Smith MT, Wang Y, Skibola CF, Slater DJ, Lo Nigro L, Nowell PC, Lange BJ, Felix CA. Low NAD (P)H:quinone oxidoreductase activity is associated with increased risk of leukemia with MLL translocations in infants and children. Blood 2002;100:4590-4593. [PubMed: 12393620]

50. Chen H, Eastmond DA. Topoisomerase inhibition by phenolic metabolites: a potential mechanism for benzene's clastogenic effects. Carcinogenesis 1995;16:2301-2307. [PubMed: 7586126]

51. Hutt AM, Kalf GF. Inhibition of human DNA topoisomerase II by hydroquinone and $p$-benzoquinone, reactive metabolites of benzene. Environ. Health Perspect 1996;104(Suppl 6):1265-1269. [PubMed: 9118903]

52. Frantz CE, Chen H, Eastmond DA. Inhibition of human topoisomerase II in vitro by bioactive benzene metabolites. Environ. Health Perspect 1996;104(Suppl 6):1319-1323. [PubMed: 9118913]

53. Srinivasan A, Robertson LW, Ludewig G. Sulfhydryl binding and topoisomerase inhibition by PCB metabolites. Chem. Res. Toxicol 2002;15:497-505. [PubMed: 11952335] 
54. Eastmond DA, Mondrala ST, Hasegawa L. Topoisomerase II inhibition by myeloperoxidase-activated hydroquinone: a potential mechanism underlying the genotoxic and carcinogenic effects of benzene. Chem. Biol. Interact 2005;153-154:207-216. [PubMed: 15935818]

55. Worland ST, Wang JC. Inducible overexpression, purification, and active site mapping of DNA topoisomerase II from the yeast Saccharomyces cerevisiae. J. Biol. Chem 1989;264:4412-4416. [PubMed: 2538443]

56. Elsea SH, Hsiung Y, Nitiss JL, Osheroff N. A yeast type II topoisomerase selected for resistance to quinolones. Mutation of histidine 1012 to tyrosine confers resistance to nonintercalative drugs but hypersensitivity to ellipticine. J. Biol. Chem 1995;270:1913-1920. [PubMed: 7829529]

57. Kingma PS, Greider CA, Osheroff N. Spontaneous DNA lesions poison human topoisomerase II $\alpha$ and stimulate cleavage proximal to leukemic 11q23 chromosomal breakpoints. Biochemistry 1997;36:5934-5939. [PubMed: 9166762]

58. Amaro AR, Oakley GG, Bauer U, Spielmann HP, Robertson LW. Metabolic activation of PCBs to quinones: reactivity toward nitrogen and sulfur nucleophiles and influence of superoxide dismutase. Chem. Res. Toxicol 1996;9:623-629. [PubMed: 8728508]

59. Eng JK, McCormack AL, Yates JRI. An approach to correlate tandem mass-spectral data of peptides with amino-acid-sequences in a protein database. J. Am. Soc. Mass Spec 1994;5:976-998.

60. Hansen BT, Davey SW, Ham AJ, Liebler DC. P-Mod: an algorithm and software to map modifications to peptide sequences using tandem MS data. J Proteome Res 2005;4:358-368. [PubMed: 15822911]

61. Wasserman RA, Austin CA, Fisher LM, Wang JC. Use of yeast in the study of anticancer drugs targeting DNA topoisomerases: expression of a functional recombinant human DNA topoisomerase II alpha in yeast. Cancer Res 1993;53:3591-3596. [PubMed: 8393377]

62. O'Reilly EK, Kreuzer KN. A unique type II topoisomerase mutant that is hypersensitive to a broad range of cleavage-inducing antitumor agents. Biochemistry 2002;41:7989-7997. [PubMed: 12069589]

63. Fortune JM, Osheroff N. Merbarone inhibits the catalytic activity of human topoisomerase II $\alpha$ by blocking DNA cleavage. J. Biol. Chem 1998;273:17643-17650. [PubMed: 9651360]

64. Byl JA, Fortune JM, Burden DA, Nitiss JL, Utsugi T, Yamada Y, Osheroff N. DNA topoisomerases as targets for the anticancer drug TAS-103: primary cellular target and DNA cleavage enhancement. Biochemistry 1999;38:15573-15579. [PubMed: 10569941]

65. Fortune JM, Dickey JS, Lavrukhin OV, Van Etten JL, Lloyd RS, Osheroff N. Site-specific DNA cleavage by Chlorella virus topoisomerase II. Biochemistry 2002;41:11761-11769. [PubMed: 12269818]

66. Fortune JM, Lavrukhin OV, Gurnon JR, Van Etten JL, Lloyd RS, Osheroff N. Topoisomerase II from Chlorella virus PBCV-1 has an exceptionally high DNA cleavage activity. J. Biol. Chem 2001;276:24401-24408. [PubMed: 11323425]

67. Vaughn J, Huang S, Wessel I, Sorensen TK, Hsieh T, Jensen LH, Jensen PB, Sehested M, Nitiss JL. Stability of the topoisomerase II closed clamp conformation may influence DNA-stimulated ATP hydrolysis. J. Biol. Chem 2005;280:11920-11929. [PubMed: 15647268]

68. Berger JM, Gamblin SJ, Harrison SC, Wang JC. Structure and mechanism of DNA topoisomerase II. Nature 1996;379:225-232. [PubMed: 8538787]

69. Classen S, Olland S, Berger JM. Structure of the topoisomerase II ATPase region and its mechanism of inhibition by the chemotherapeutic agent ICRF-187. Proc. Natl. Acad. Sci. U S A 2003;100:1062910634. [PubMed: 12963818]

70. Hasinoff BB, Wu X, Krokhin OV, Ens W, Standing KG, Nitiss JL, Sivaram T, Giorgianni A, Yang S, Jiang Y, Yalowich JC. Biochemical and proteomics approaches to characterize topoisomerase IIalpha cysteines and DNA as targets responsible for cisplatin-induced inhibition of topoisomerase IIalpha. Mol. Pharmacol 2005;67:937-947. [PubMed: 15602006]

71. Pommier Y, Marchand C. Interfacial inhibitors of protein-nucleic acid interactions. Curr. Med. Chem. Anti-Canc. Agents 2005;5:421-429. 


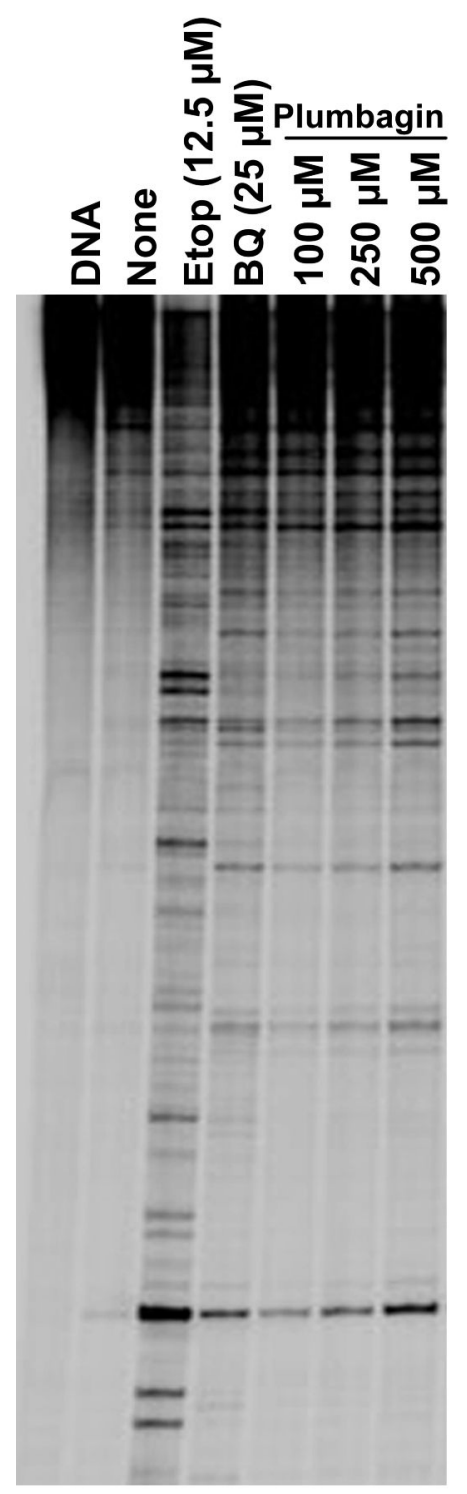<smiles>O=C1C=CC(=O)C=C1</smiles>

\section{Benzoquinone}<smiles>CC1=CC(=O)c2c(O)cccc2C1=O</smiles>

Plumbagin

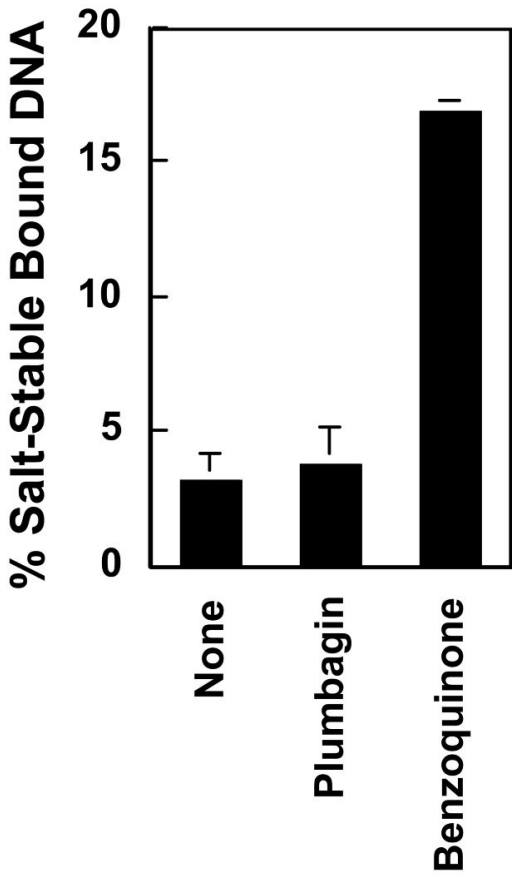

\section{Drug}

Figure 1.

DNA cleavage enhancement by human topoisomerase II $\alpha$ in the presence of plumbagin. Upper Right: The structures of plumbagin and benzoquinone are shown. Reactive sites on the compounds are indicated by stars. Left: An autoradiogram of a polyacrylamide gel of DNA cleavage reactions is shown. Assays contained no compound (None), $12.5 \mu \mathrm{M}$ etoposide, or $25 \mu \mathrm{M}$ benzoquinone or $100-500 \mu \mathrm{M}$ plumbagin. A DNA control is shown in the far left lane. Data are representative of two independent experiments. Lower Right: Results of topoisomerase II protein clamp closing assays are shown. The bar graph represents levels of salt-stable bound DNA formed when topoisomerase II-DNA complexes were treated with no 
drug (None), $250 \mu \mathrm{M}$ plumbagin or $100 \mu \mathrm{M}$ benzoquinone. Error bars represent the standard deviation of four independent experiments. 


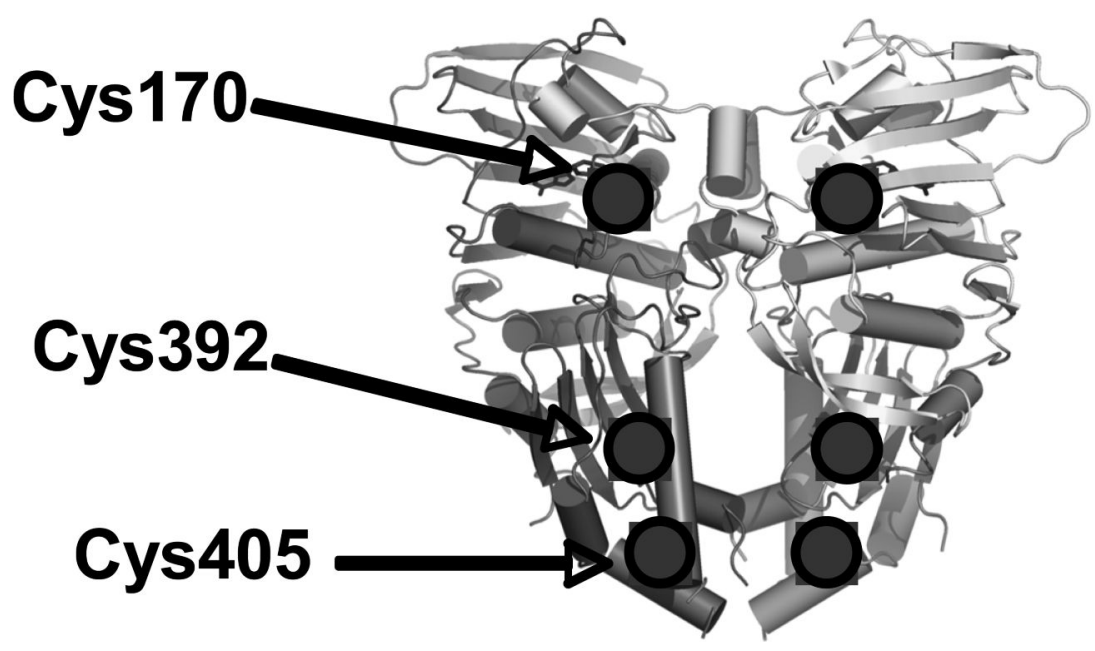

Cys455

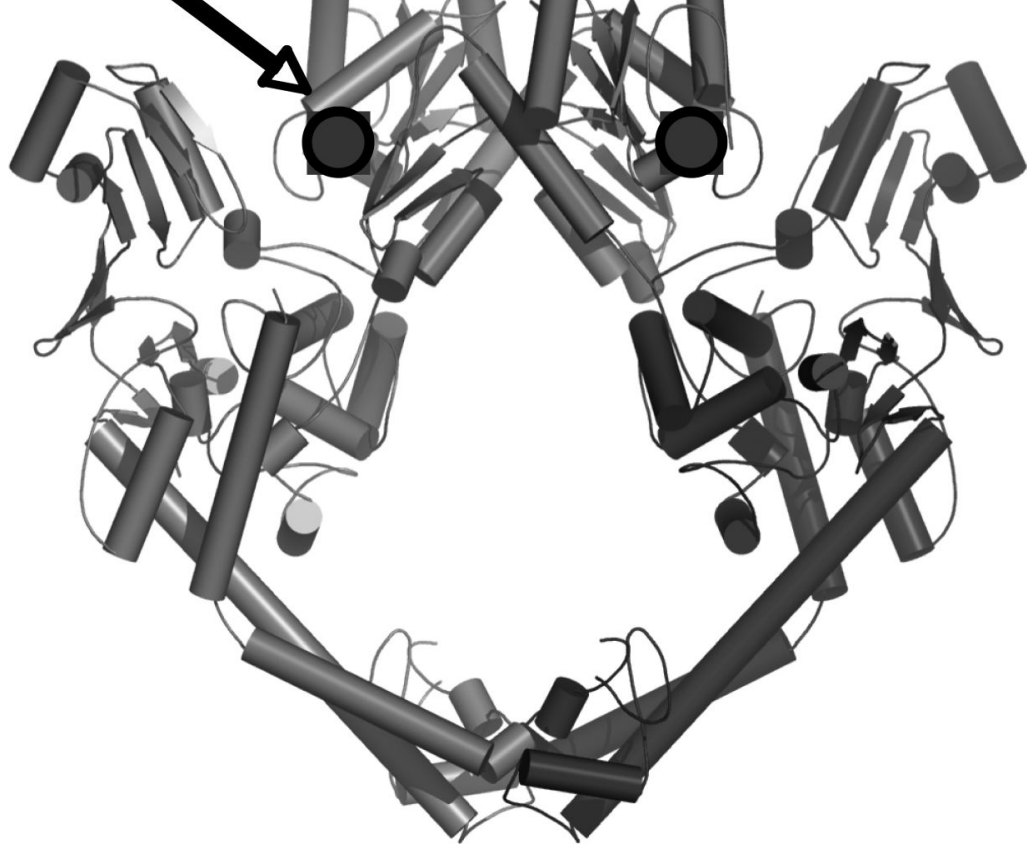

Figure 2.

Plumbagin adducts to cysteine residues in human topoisomerase II $\alpha$. Residues adducted by quinones were identified by mass spectrometry. A composite of the crystal structures of the yeast catalytic core and $\mathrm{N}$-terminal domain is shown and the locations of the homologous cysteine residues adducted in human topoisomerase II $\alpha$ are indicated by shaded circles. These residues were mutated to alanines using mutagenesis PCR to evaluate their role in quinone action. Adapted from Refs. $(68,69)$. 

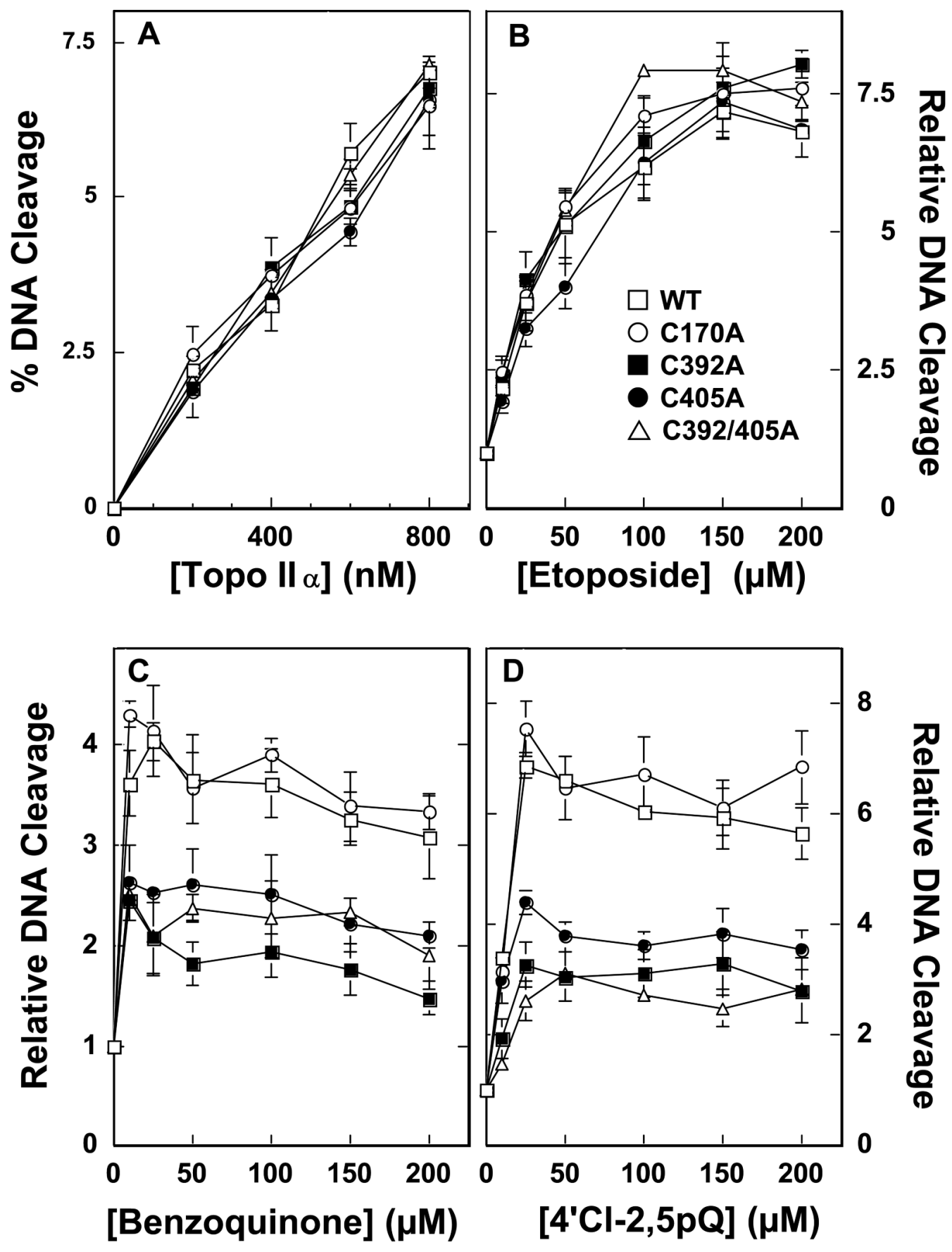

Figure 3.

DNA cleavage activity of mutant human topoisomerase II $\alpha$ enzymes. Panel A: Cleavage activity was assessed using $0-800 \mathrm{nM}$ topoisomerase II $\alpha$ in the absence of quinones. Assay mixtures contained wild-type enzyme (WT, open squares), top2 $\alpha \mathrm{C} 170 \mathrm{~A}$ (C170A, open circles), top $2 \alpha \mathrm{C} 392 \mathrm{~A}$ (C392A, filled squares), top $2 \alpha \mathrm{C} 405 \mathrm{~A}$ (C405A, filled circles), or top2 $\alpha \mathrm{C} 392 / 405 \mathrm{~A}$ (C392/405A, open triangles). Panel B: DNA cleavage reactions were carried out in the presence of 0-200 $\mu \mathrm{M}$ etoposide. Panel C: DNA cleavage reactions were carried out in the presence of 0-200 $\mu \mathrm{M}$ benzoquinone. Panel D: DNA cleavage reactions were carried out in the presence of $0-200 \mu \mathrm{M} 4^{\prime} \mathrm{Cl}-2,5 \mathrm{pQ}$. Error bars represent the standard deviation of at least three independent experiments. 

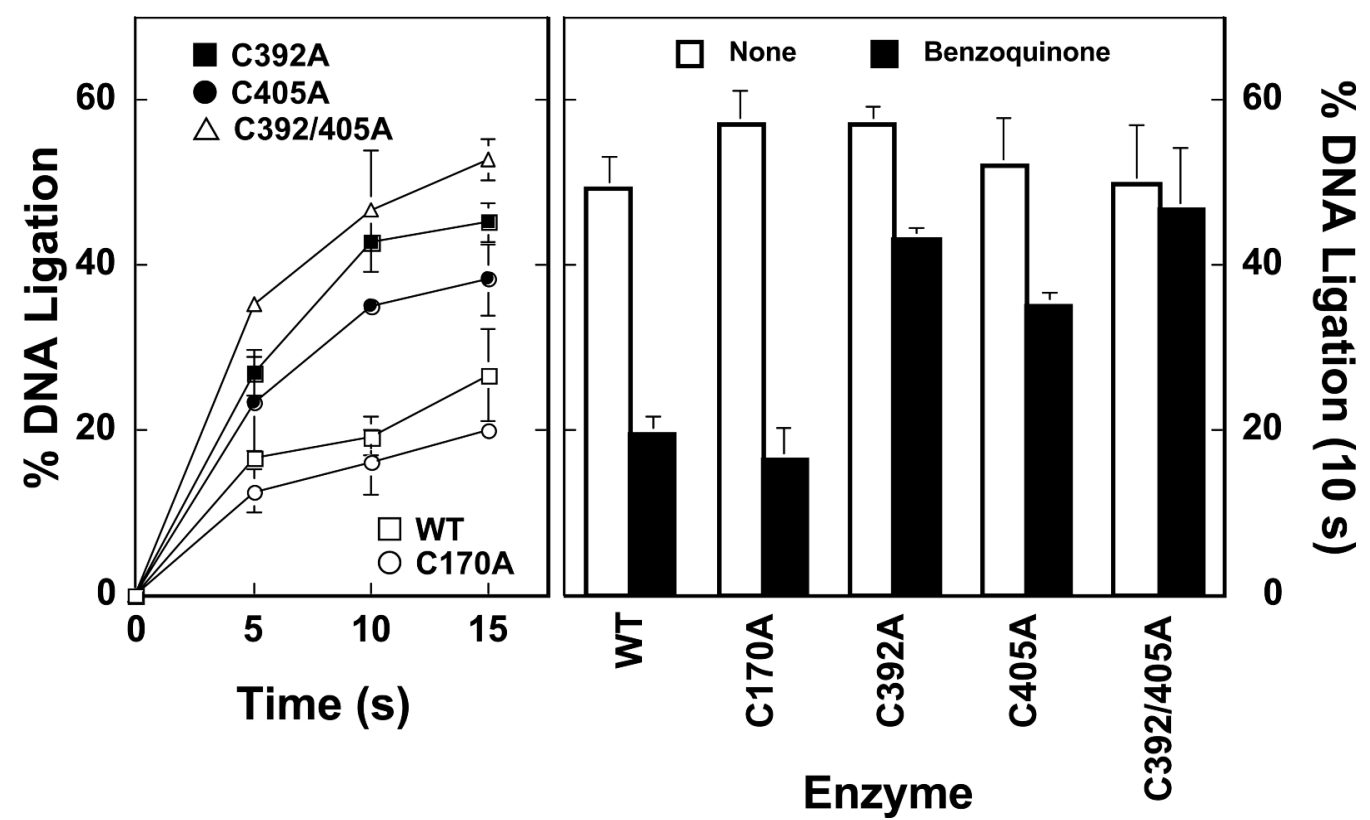

Figure 4.

Quinone-resistant mutant human topoisomerase II $\alpha$ enzymes display higher rates of DNA religation in the presence of benzoquinone. Left Panel: DNA religation reactions were carried out in the presence of $100 \mu \mathrm{M}$ benzoquinone. Assay mixtures contained wild-type enzyme (WT, open squares), top2 $\alpha \mathrm{C} 170 \mathrm{~A}$ (C170A, open circles), top2 $\alpha \mathrm{C} 392 \mathrm{~A}$ (C392A, filled squares), top $2 \alpha \mathrm{C} 405 \mathrm{~A}$ (C405A, filled circles), or top2 $\alpha \mathrm{C} 392 / 405 \mathrm{~A}$ (C392/405A, open triangles). Samples were incubated at $37{ }^{\circ} \mathrm{C}$ to establish DNA cleavage/religation equilibria. Reactions were shifted to $0{ }^{\circ} \mathrm{C}$ to initiate religation. DNA religation was quantified by the loss of linear cleaved molecules. Right Panel: Representative DNA religation data at $10 \mathrm{~s}$ is shown. DNA cleavage/religation equilibria were established in the presence (filled bars) or absence (None, open bars) of benzoquinone. Error bars represent the standard deviation of at least three independent experiments. 


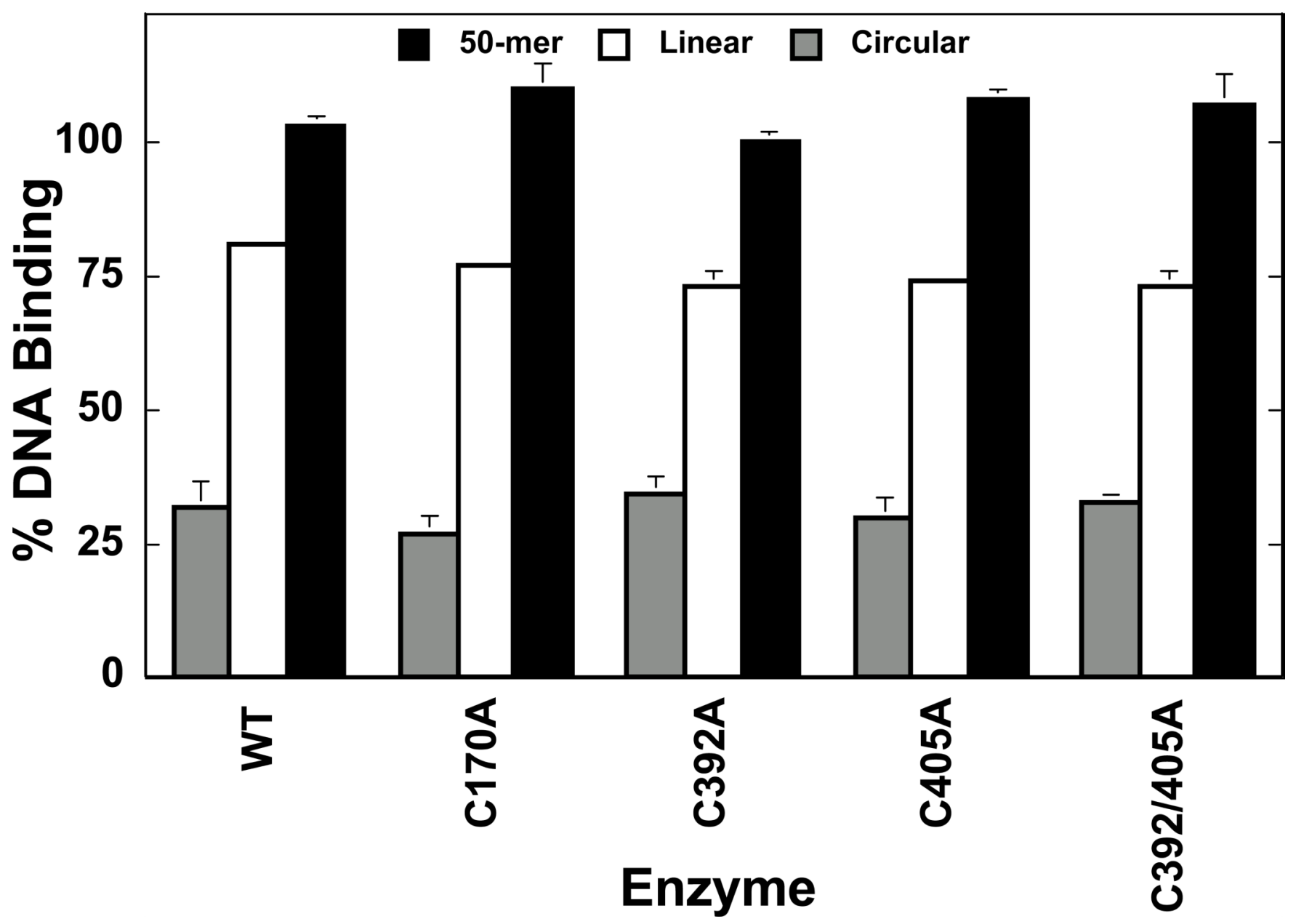

Figure 5.

Substrate-dependent effects of benzoquinone on mutant topoisomerase II $\alpha$-DNA binding. Assays employed a negatively supercoiled circular plasmid (shaded bars), a linear plasmid (open bars), or a duplex 50-mer oligonucleotide (filled bars) as the substrate. Enzymes were incubated with $100 \mu \mathrm{M}$ benzoquinone for $5 \mathrm{~min}$ prior to the addition of DNA. DNA binding in the absence of benzoquinone was set to $100 \%$. Error bars represent the standard deviation of at least three independent experiments. 

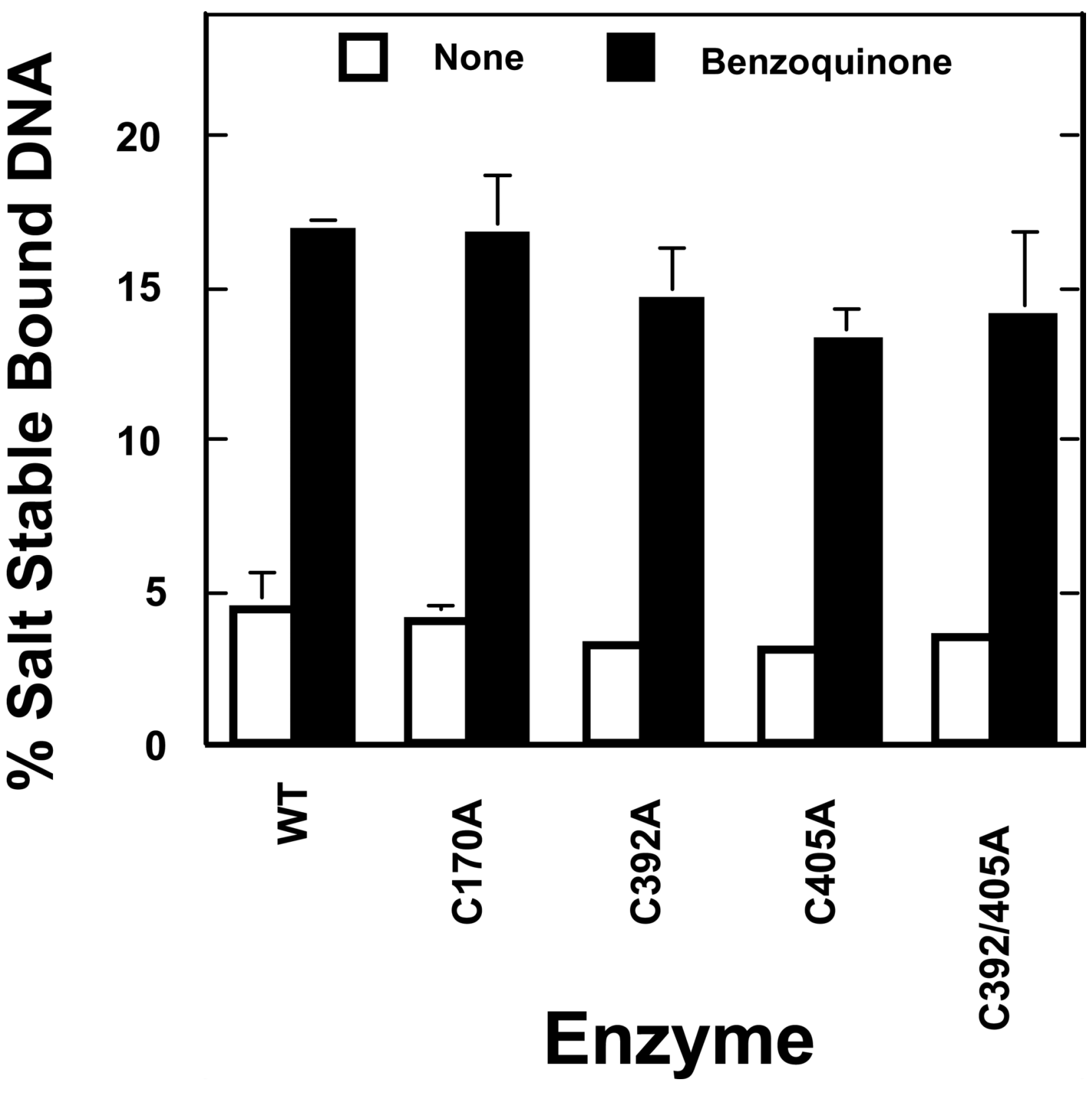

Figure 6.

Benzoquinone blocks the N-terminal gate of mutant human topoisomerase II $\alpha$ enzymes. Filter binding assays were used to analyze the salt-stable closed-clamp of topoisomerase II. EnzymeDNA complexes were established and further incubated in the absence (None, open bars) or presence (filled bars) of $100 \mu \mathrm{M}$ benzoquinone. Samples were applied to glass fiber filters, DNA was eluted by sequential washes in low salt, high salt, and SDS, and eluted samples were subjected to electrophoresis in an agarose gel. Salt-stable non-covalent enzyme-DNA complexes were quantified by the amount of plasmid that did not elute until the SDS wash relative to the total plasmid eluted in all three washes. Error bars represent the standard deviation of at least three independent experiments. 


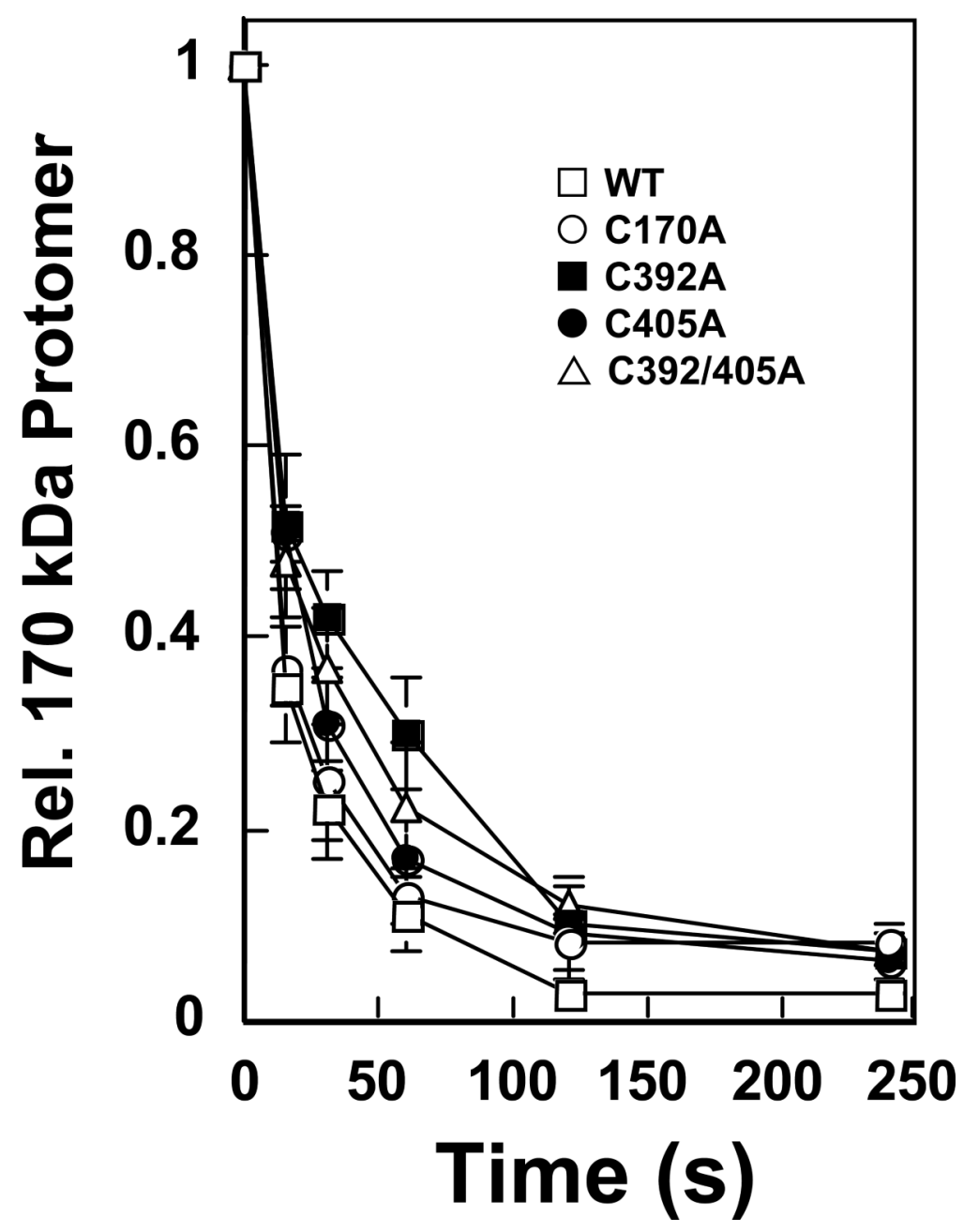

Figure 7.

Benzoquinone crosslinks the protomer subunits of mutant human topoisomerase II $\alpha$ enzymes. Assay mixtures contained $135 \mathrm{nM}$ wild-type enzyme (WT, open squares), top $2 \alpha \mathrm{C} 170 \mathrm{~A}$ (C170A, open circles), top2 $\alpha$ C392A (C392A, filled squares), top2 $\alpha \mathrm{C} 405 \mathrm{~A}$ (C405A, filled circles), or top $2 \alpha \mathrm{C} 392 / 405 \mathrm{~A}$ (C392/405A, open triangles) that was treated with $100 \mu \mathrm{M}$ benzoquinone for 0-4 min. Samples were subject to electrophoresis in a polyacrylamide gel and protein was visualized by coomassie staining. The level of $170 \mathrm{kDa}$ enzyme protomer that was present in the absence of benzoquinone was set to 1 . Error bars represent the standard deviation of at least three independent experiments. 